第 128 回日本循環器学会近畿地方会 初期研修医セッション 優秀演題賞

\title{
心筋梗塞発症後急性期に心襄水貯留を認めた急性心膜炎の1例
}

北井 順也，黒田 真衣子，田巻 庸道，演㠃 眞希，濱口 侑大，美馬 響，小島 秀規， 山﨑 誠太，田村 章憲，岡本 寛樹，大林 祐樹，張田 健志，西内 英，坂本 二郎， 榎本 操一郎, 三宅 誠, 近藤 博和, 田村 俊寛

天理よろづ相談所病院 循環器内科

85 歳男性. 前日からの胸部不快感を自覚し救急搬送された. 下壁誘導と V1-V6 誘導の ST 上昇と心筋逸脱酵素 上昇を認め急性冠症候群が疑われた。緊急冠動脈造影では左回旋枝に $100 \%$ 閉塞を認め，血栓吸引と薬剤溶出性 ステント留置により再灌流に成功した。しかし術後もST は上昇し続け，心膜摩擦音を聴取したことから急性心膜 炎を疑い第 4 病日より高用量アスピリンを開始した．第 5 病日に約 6 時間の経過でショック状態に至り，心囊水 著増を認めた。 心膜炎増悪と心破裂の可能性を考えたが高齢であり保存的加療の方針となった. 第 7 病日にアス ピリンを増量し，第 13 病日には心囊水消失とST 改善を認めた. 本症例は心筋梗塞発症後に急激な心囊水の増加 を認め複数の病態が考えられた症例であり，若干の文献的考察を踏まえて報告する.

キーワード : 急性心膜炎，急性心筋梗塞，心囊水貯留

\section{Acute pericarditis with pericardial effusion in the acute phase of myocardial infarction: A case report}

Junya Kitai, Maiko Kuroda, Yodo Tamaki, Maki Hamasaki, Yukihiro Hamaguchi, Hibiki Mima, Hidenori Kojima, Seita Yamasaki, Akinori Tamura, Hiroki Okamoto, Yuki Obayashi, Takeshi Harita, Suguru Nishiuchi, Jiro Sakamoto, Soichiro Enomoto, Makoto Miyake, Hirokazu Kondo, Toshihiro Tamura

Department of Cardiology, Tenri Hospital 
キースライド

1

\section{〈症例: 85歳男性〉}

\section{【主訴】胸部絞扼感}

【現病歴】

来院前日に心窩部痛を自覚し、近医を受診した。電 図で下壁誘導のST上算を認め、当院に救急搬送された。

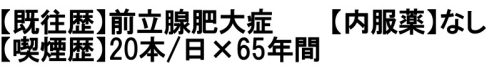

\section{【現症】}

血压 $85 / 57 \mathrm{mmHg}$ 脈拍 $71 \mathrm{bpm}$ 体温 $37.2^{\circ} \mathrm{C}$ $\mathrm{Sp02}$ 95\%(室内気)

心雑音聴取せず両肺野にcoarse cracklesを聴取 四肢に浮腫なし 末梢冷感あり

3

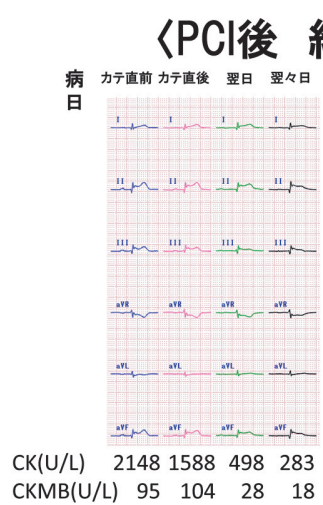

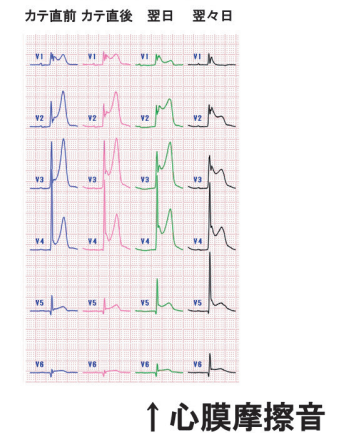

5

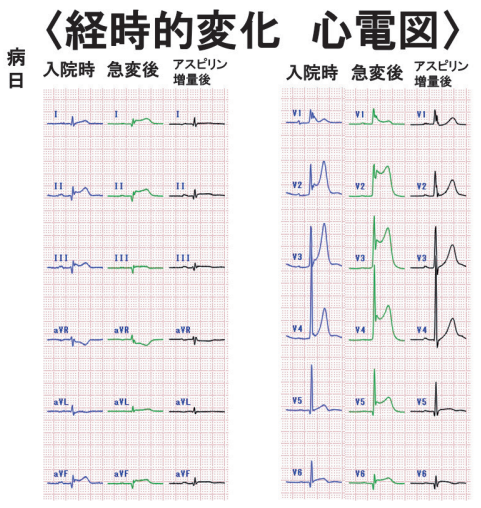

7

\section{〈考察〉}

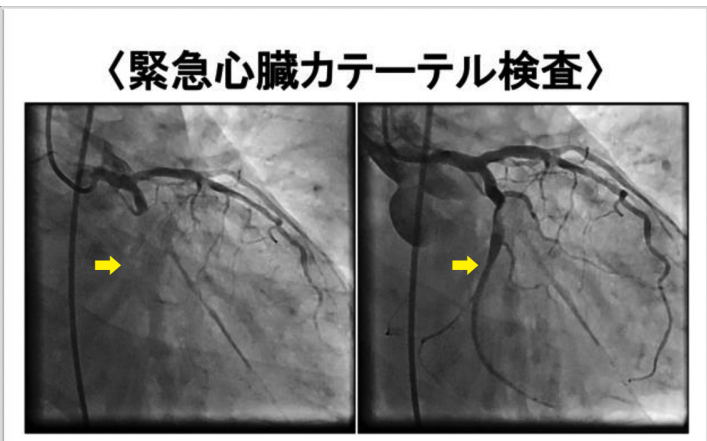

LCX \#11 100\% 完全閉塞 $\rightarrow$ 血栓吸引、赤色血栓回収 \#11に薬剤溶出性ステント(Xience 4.0*12)を留置した。

4

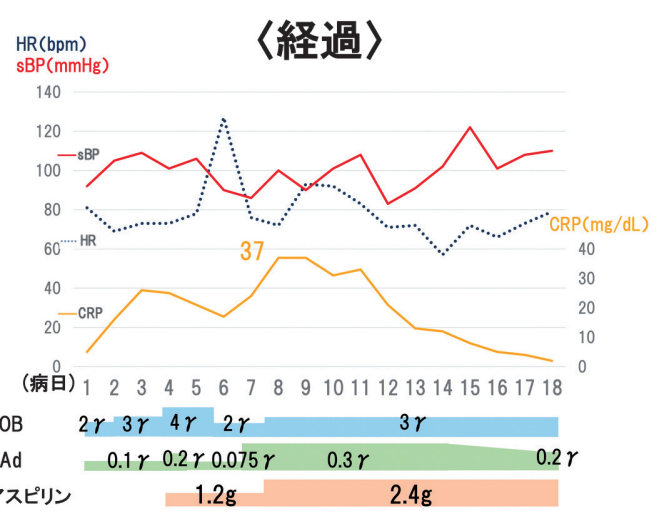

6

\section{〈心エコ一図 継時的変化〉}

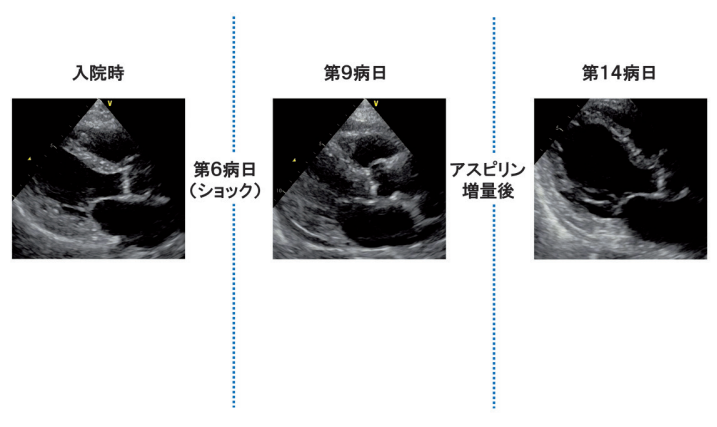

8

\section{〈結語〉}

心筋梗塞発症後急性期の急性心膜炎に 高用量アスピリンが有効であった 